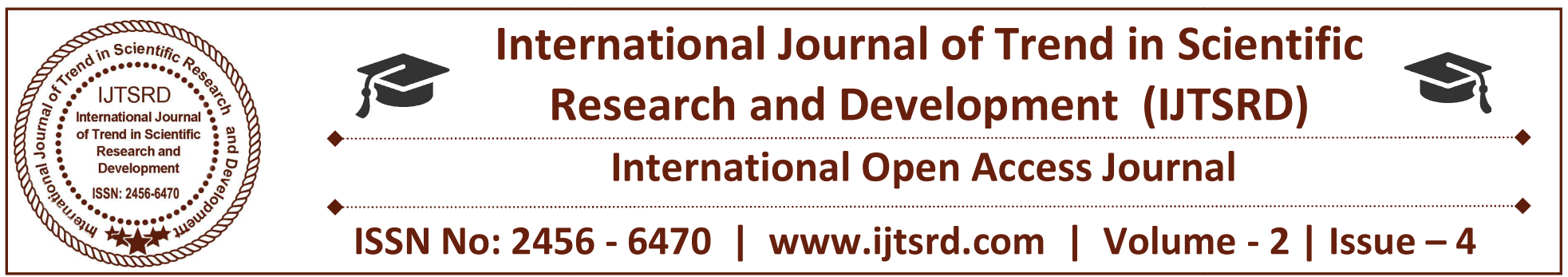

\title{
Heat Treatment and Alloying of Spherulitic Graphite Cast Iron for Intensification of Properties
}

\author{
Yawer Hamid \\ Department of Mechanical Engineering (M. Tech in Industrial and Production) \\ GGGI, University of Kurukshetra, Haryana, India
}

\section{ABSTRACT}

Spheroidal graphite cast iron or Spherulitic cast iron is described as a high carbon containing, iron based composite in which the graphite is accessible in negligible, round shapes rather than in the condition of pieces. Spherulitic cast iron or spheroidal graphite cast iron is at times implied as adaptable iron, as it has graphite as spheroids (ferritic or pearlitic) embedded in the steel system. These handles of graphite are confined clearly from the liquid in the midst of the technique of solidifying. The handles are more standard, sharp, little and constitute simply little districts of weakness in a steel-like framework. In light of this the mechanical properties of pliable irons are associated clearly to the quality and adaptability of the system show simply like the example of steels. This one of a kind property empowers ductile iron to be utilized for various modern applications . The astounding blend of mechanical properties got in Spherulitic cast iron can additionally be upgraded by the heatth treatment. The latest advancement in such manner is the creation of Austempered Ductile Iron (ADI). By adjusting the austempering treatment at first acquainted for steels with DI, it has been demonstrated that the subsequent metallurgical structures cast properties that positively contrast with those of steel while exploiting a close net-shape fabricating process. It upgrades the rigidity, furnishes better wear opposition alongside great erosion obstruction, greyinishes commotion and vibration in the segments or parts.

Therefore, flexible iron or spherulitic cast iron is austempered when a blend of various good properties are required. In any case, this sort of treatment is bit dubious and it requires controlled heating and isothermal holding of the material. So it is fundamental to locate some alluring strategies for property upgrade in Spherulitic cast iron.

\section{INTRODUCTION}

Ductile Iron is likewise ordinarily known as "Nodular Iron" or Spheriodial graphite (S.G) iron was licensed in 1948. With a grandiose climb being produced work in 1950 inside 10 years ductile iron was broadly used as a piece of Industries as a predominant planning material.

Graphite is present as spheroids in the ducile iron which gives it unusual combination of properties. By adding a very small, but specific amount of $\mathrm{Mg} \& \mathrm{Ce}$ or both to molten iron of proper composition this mode of solidification is obtained. Like malleable iron, Ductile Iron exhibits a linear stress-strain ratio; a considerable rang of yield strengths and as its name implies ductility. A wide range of sizes with sections which are very thin or very thick in the castings are made by ductile iron.

The mechanical properties and microstructure of heat treated flexible iron with two distinct evaluations, and to contrast these properties and diverse treatment conditions. Carbon instantly diffuses from the spheroids to drench the austenite organize when it is heated into the austenite temperature range. Carbon returns to the graphite "sinks" on direct cooling, by judiciousness of which carbon substance of the austenite gets diminished. To heat treat and to construct the extent of properties in malleable iron openness of excess carbon and the ability to trade it 
between the framework and the handles makes it less requesting.

Experiments have shown that proper heat treatment methods can improve the properties of Cast Iron. What's more, sometimes it might even dominate the advantages of steel over Cast Iron. Countless number of researchers are dealing with austempered Cast Iron which demonstrates great combination of properties and in some cases it may even overshadow the advantages of steel over Cast Iron.
EXPERIMENTAL TECHNIQUE

The experimental procedure for the project work can be listed as:

Preparation of Specimen, Tensile test, Heat treatment process, Hardness test, Study of mechanical properties and study of Microstructure.

Two evaluations of malleable iron $\mathrm{N} 1$ and $\mathrm{N} 2$ were utilized one containing copper, while other was without copper whose Chemical creations are tabulated in table 1 and table 2 seperately.

\begin{tabular}{|l|l|l|l|l|l|l|l|l|l|}
\hline Specimen & C \% & Si \% & Cu \% & Mn \% & P \% & Mg \% & Cr \% & Ni \% & S \% \\
\hline $\begin{array}{l}\text { With } \\
\text { N1) }\end{array}$ & 3.52 & 2.12 & 0.47 & 0.21 & 0.029 & 0.038 & 0.018 & 0.17 & 0.013 \\
\hline
\end{tabular}

Table 1 Chemical composition of N1

\begin{tabular}{|l|l|l|l|l|l|l|l|l|l|}
\hline Specimen & $\mathrm{C} \%$ & $\mathrm{Si} \%$ & $\mathrm{Cu} \%$ & $\mathrm{Mn} \%$ & $\mathrm{P} \%$ & $\mathrm{Mg} \%$ & $\mathrm{Cr} \%$ & $\mathrm{Ni} \%$ & $\mathrm{~S} \%$ \\
\hline $\begin{array}{l}\text { Without } \mathrm{Cu} \\
\text { (N2) }\end{array}$ & 3.55 & 2.32 & 0.001 & 0.18 & 0.031 & 0.042 & 0.02 & 0.23 & 0.014 \\
\hline
\end{tabular}

Table 2 Chemical composition of $\mathrm{N} 2$

The specimen size should be compatible to the machine specifications. The specimens were prepared from the procured samples followed by machining operations like milling, grinding and turning to obtain the required dimensions.

Gauge dia $=14 \mathrm{~mm}$

Grip dia $=20 \mathrm{~mm}$

Grip length $=50 \mathrm{~mm}$

Gauge length $=70 \mathrm{~mm}$.

Then for testing different mechanical properties the specimen was taken to UTS machine after heat treatment.

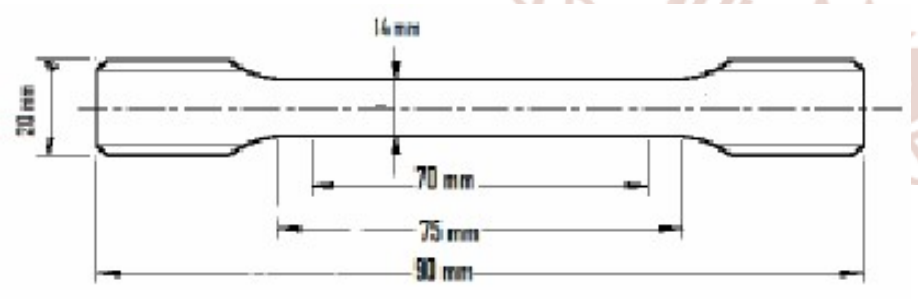

Tensile test specimen

\section{Heat Treatment process}

For lattice microstructures and related mechanical properties which are not promptly gotten in the as-cast condition in malleable cast iron the essential heat treatment is done. Austenitizing and Austempering are the two phases of heat treatment. Solidifying, normalizing and austempering heat treatment, include austenitization, which is trailed by isothermal response, or a mix of both. The main objective of the project is comparison of mechanical properties after carrying out the heat treatment.

Twenty-six samples from each grade were taken in a group to homogenize the samples kept them in a muffle furnace for one hour at $900 \mathrm{C}^{\circ}$ (austenization), after that, two samples from each grade were normalized by rapid cooling in still air for 30 minutes, and 2 samples from each grade quenched in oil for 20 minutes. For Tempering treatment: After austenization, 6 samples from each grade were tempered at $300^{\circ} \mathrm{C}, 450^{\circ} \mathrm{C}$ and $600^{\circ} \mathrm{C}$ for $1 \mathrm{hr}$, and for austempering, 16 of the samples from each grade were heated at $900^{\circ} \mathrm{C}$ for $\mathrm{I} \mathrm{hr}$ for anstenization and then 8 of this sample transferred quickly to a salt bath (salt combination was $50 \mathrm{wt} \% \mathrm{NaNO} 3$ and $50 \mathrm{wt} \%$ $\mathrm{KNO} 3$ ) maintained at $300^{\circ} \mathrm{C}$, and the other samples to a bath of $350^{\circ} \mathrm{C}$. The samples were kept in the salt baths for different times as: $0.5 \mathrm{hr}, 1 \mathrm{hr}, 1.5 \mathrm{hr}$ and 2.0 hrs. 


\section{Tests Measurements:}

Rockwell hardness test method as defined in ASTM E-18, is the most commonly used hardness test method.The sample was put on the specimen holder and small load of $10 \mathrm{kgf}$ was applied by ball intender. After the small load, an additional load i,e the major load of 100kgf was applied so that the total required test load can be obtained. After holding for a predetermined span of time this major load was then released and the preliminary test force was held for a specified dwell time, the final depth of indentation was measured.

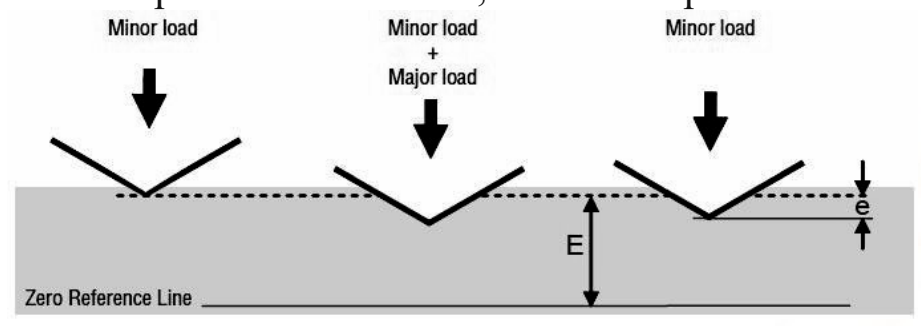

\section{Tensile Testing Measurement}

The machine used was Instron Universal Testing Machine according to ASTM (A 370- 2002) Process followed:

The details were fed into the testing machine The distance between the jaws was fixed according to the gauge length of the specimen The specimen was gripped by the jaws after inserting into the machine.

Loading was done till the specimen failed (Maximum load $=150 \mathrm{KN}$ ) The corresponding readings generated for Ultimate Tensile Strength, $\%$ elongation \& Yield Stength were noted.

\section{RESULTS AND DISCUSSION Mechanical Properties}

The mechanical properties measured by using Universal testing machine and greyensions of specimen was carried out according to ASTM (A 370-2002), are castn in Table 3 and Table 4 , lists the mechanical properties of tensile strength, yield stress, elongation and hardness of ductile irons (with and without $\mathrm{Cu}$ ) N1, N2 respectively.

Table A Tensile strength, yield stress, elongation and hardness of Tempered ductile iron with and without Copper

\begin{tabular}{|c|c|c|c|c|c|c|}
\hline \multicolumn{7}{|c|}{ TREATMIENT } \\
\hline $\begin{array}{l}\text { Tempered D.I } \\
\text { with } \mathrm{Cu}(\mathrm{N} 2)\end{array}$ & As Received & Normalized & Oil Quench & $\begin{array}{l}\text { Tempered } \\
\text { at } 300^{\circ} \mathrm{C}\end{array}$ & $\begin{array}{l}\text { Tempered } \\
\text { at } 450^{\circ} \mathrm{C}\end{array}$ & $\begin{array}{l}\text { Tempered } \\
\text { at } 600^{\circ} \mathrm{C}\end{array}$ \\
\hline UTS ( MPa ) & 367 & 374 & 451 & 437 & 402 & 381 \\
\hline Y.S ( MPa ) & 191 & 193 & 198 & 205 & 237 & 267 \\
\hline$\%$ & 5.1 & 4.4 & 3.5 & 6.9 & 10.3 & 17.85 \\
\hline $\mathrm{H}$ (RA) & 41 & 57 & 71 & 68 & 63 & 59 \\
\hline
\end{tabular}

\begin{tabular}{|l|l|l|l|l|l|l|}
\hline \multicolumn{7}{|c|}{ TREATMENT } \\
\hline $\begin{array}{l}\text { Tempered D.I } \\
\text { Without Cu (N2) }\end{array}$ & As Received & Normalized & $\begin{array}{l}\text { Oil } \\
\text { Quench }\end{array}$ & $\begin{array}{l}\text { Tempered } \\
\text { at 300 }{ }^{\circ} \mathrm{C}\end{array}$ & $\begin{array}{l}\text { Tempered } \\
\text { at } 450^{\circ} \mathrm{C}\end{array}$ & $\begin{array}{l}\text { Temperd } \\
\text { at } 600^{\circ} \mathrm{C}\end{array}$ \\
\hline UTS ( MPa $)$ & 276 & 298 & 387 & 292 & 246 & 213 \\
\hline Y.S ( MPa $)$ & 193 & 201 & 207 & 212 & 207 & 199 \\
\hline$\%$ & 13.8 & 7.3 & 6.2 & 8.6 & 14.9 & 15.3 \\
\hline H (RA) & 43 & 64 & 70 & 69 & 58 & 57 \\
\hline
\end{tabular}


International Journal of Trend in Scientific Research and Development (IJTSRD) ISSN: 2456-6470

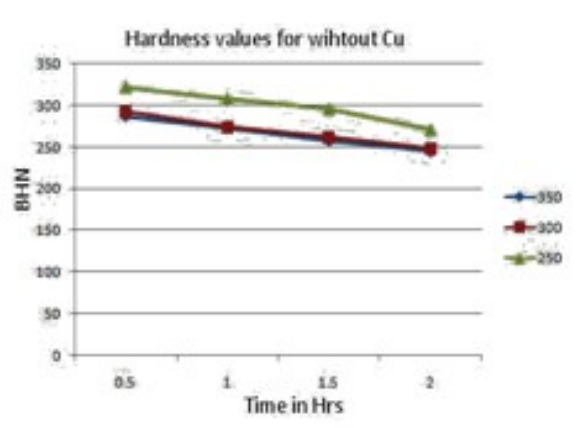

Variation of Hardness with heat treatment of sample without $\mathrm{Cu}$

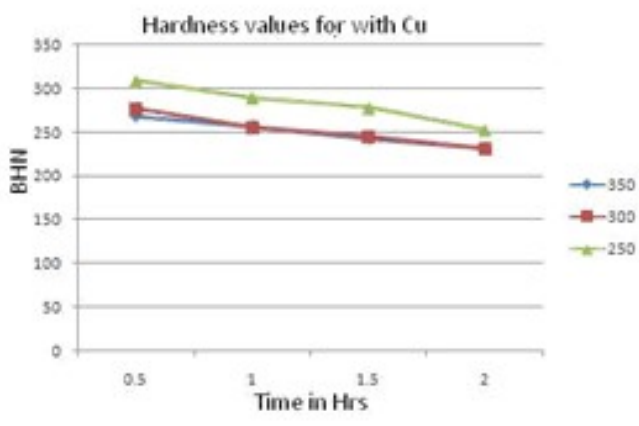

Variation of Hardness with Heat treatment of ample with $\mathrm{Cu}$

\begin{tabular}{|c|c|c|c|c|c|c|}
\hline \multirow{2}{*}{$\begin{array}{l}\text { Austempered } \\
\text { D.I with } \mathrm{Cu}\end{array}$} & \multicolumn{6}{|c|}{ TREATMIENT } \\
\hline & $\begin{array}{l}\text { As } \\
\text { Recieved }\end{array}$ & $\begin{array}{l}\text { Temperature } \\
\left({ }^{\mathrm{o}} \mathrm{c}\right)\end{array}$ & $\begin{array}{c}\text { Austempered } \\
1 / 2 \mathrm{Hr}\end{array}$ & $\begin{array}{c}\text { Austempered } \\
1.0 \mathrm{Hr}\end{array}$ & $\begin{array}{c}\text { Austempered } \\
11 / 2 \mathrm{Hr}\end{array}$ & $\begin{array}{c}\text { Austempered } \\
2.0 \mathrm{Hr}\end{array}$ \\
\hline \multirow[t]{2}{*}{ UTS (MPa) } & 370 & 300 & $856=1$ & 1021 & 1011 & 1009 \\
\hline & & 350 & 654 & 898 & 913 & 902 \\
\hline \multirow[t]{2}{*}{ Y.S (MPa) } & 322 & 300 & 641 & 88410 & 809 & 802 \\
\hline & & 350 & 478 & 632 & 599 & 601 \\
\hline \multirow[t]{2}{*}{$\%$} & 7.9 & 300 & $6.4 \quad \square$ & 6.5 & 6.7 & 6.9 \\
\hline & & 350 & 8.3 & 8.3 & 8.9 & 9.1 \\
\hline \multirow[t]{2}{*}{$\mathrm{H}(\mathrm{RA})$} & 42 & 300 & 71 & $66-1$ & 61 & 59 \\
\hline & & 350 & 69 & 61 & 57 & 51 \\
\hline
\end{tabular}

austempring of ductile iron with copper

\begin{tabular}{|c|c|c|c|c|c|c|}
\hline \multirow{2}{*}{$\begin{array}{l}\text { Austempered } \\
\text { D.I without } \\
\text { Cu. }\end{array}$} & \multicolumn{6}{|c|}{ TREATMENT } \\
\hline & $\begin{array}{l}\text { As } \\
\text { Recieved }\end{array}$ & $\begin{array}{l}\text { Tempera } \\
\text { ture }\left({ }^{\circ} \mathrm{c}\right)\end{array}$ & $\begin{array}{l}\text { Austempered } \\
1 / 2 \mathrm{Hr}=2456\end{array}$ & $\begin{array}{l}\text { Austempered } \\
61.0 \mathrm{Hr}\end{array}$ & $\begin{array}{c}\text { Austempered } \\
11 / 2 \mathrm{Hr}\end{array}$ & $\begin{array}{c}\text { Austempered } \\
2.0 \mathrm{Hrs}\end{array}$ \\
\hline \multirow[t]{2}{*}{ UTS (MPa) } & 558 & 300 & 816 & 896 & 901 & 879 \\
\hline & & 350 & 631 & 788 & 791 & 751 \\
\hline \multirow[t]{2}{*}{ Y.S (MPa) } & 267 & 300 & 628 & 797 & 718 & 764 \\
\hline & & 350 & $419=$ & 558 & 537 & 543 \\
\hline \multirow[t]{2}{*}{$\%$} & 16 & 300 & 6.2 & 7.4 & 7.9 & 7.7 \\
\hline & & 350 & 7.9 & 9.2 & 9.8 & 10.3 \\
\hline \multirow[t]{2}{*}{$\mathrm{H}(\mathrm{RA})$} & 39 & 300 & 73 & 69 & 58 & 54 \\
\hline & & 350 & 68 & 64 & 52 & 49 \\
\hline
\end{tabular}

Austempring of ductile iron without copper

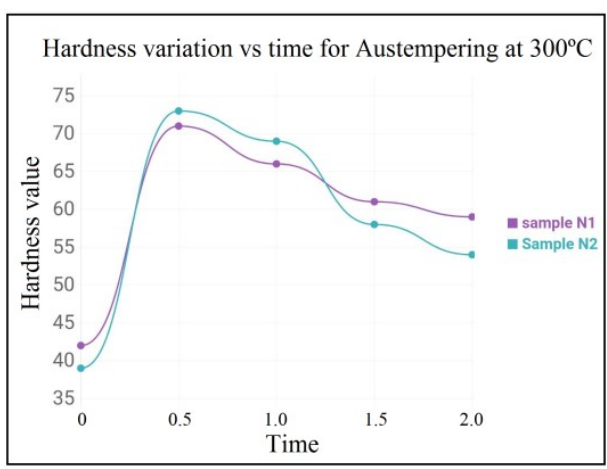

Fig 1

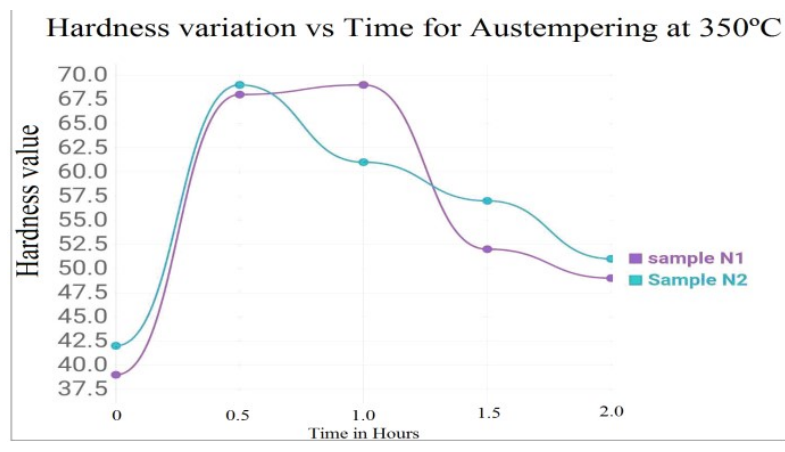

Fig 2 
Hardness of plain ADI (N2 specimen) is slightly lower than the $\mathrm{Cu}$ enriched $\mathrm{ADI}(\mathrm{N} 1$ specimen), and hardness reduces proportionally with increase in austempering time. This decrease in hardness is due to the disappearance of martensite phase. Lower austempering time yield a finer structure and therefore higher hardness was obtained. But as the holding treatment time increased further, the hardness values were again decreased due to the occurrence of coarse plate-type structure (of bainitic) matrix phase.

\section{Resultsof Elongation, Tensile Strength Elongation,} Tensile Strength

In case of tempering elongation, ultimate tensile strength and yield stress variation with temperature, of two different grades are shown below in fig $\mathrm{x}$, fig $\mathrm{y}$ and fig $\mathrm{z}$ respectively.

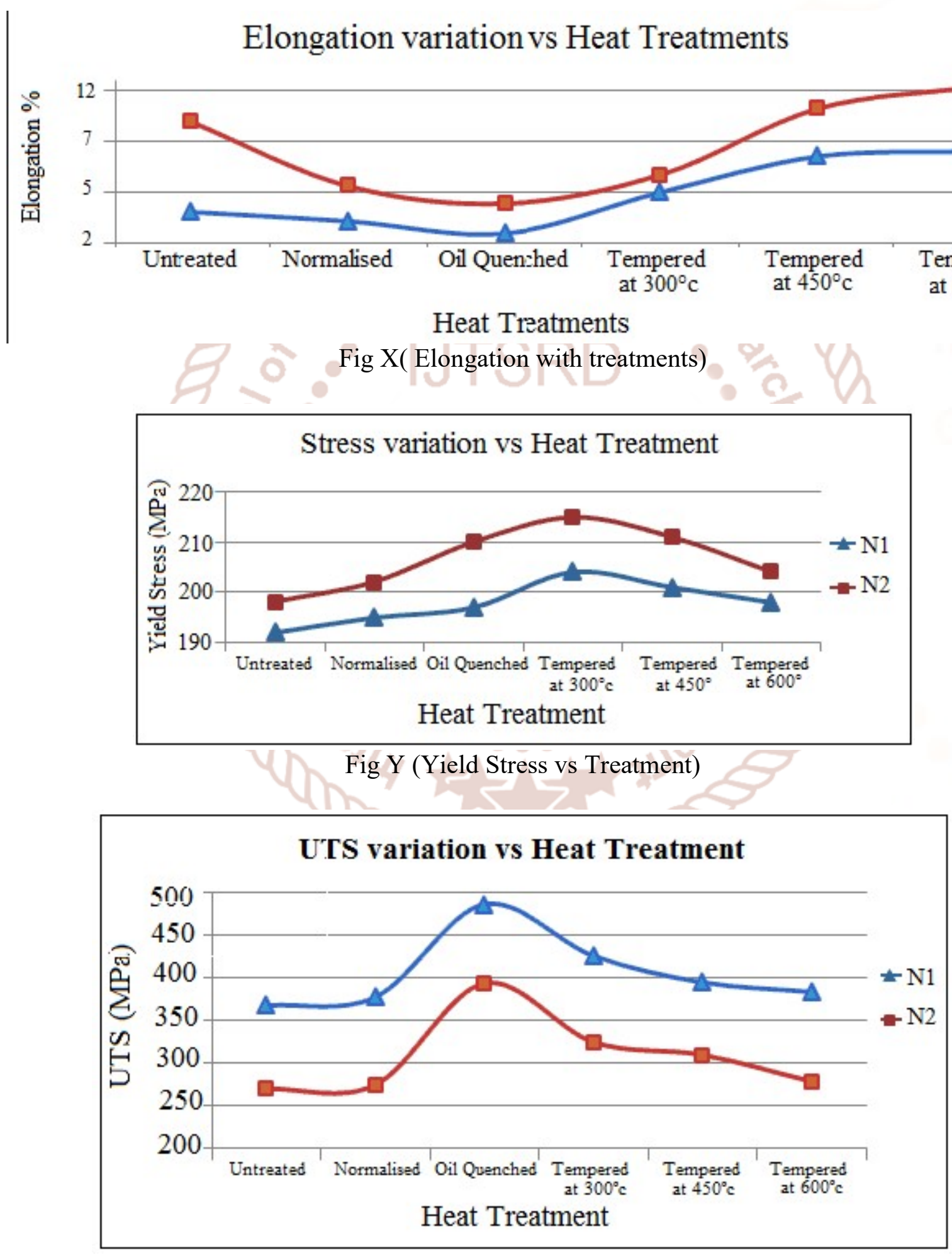

Fig Z (Ultimate tensile strength with treatment) 
International Journal of Trend in Scientific Research and Development (IJTSRD) ISSN: 2456-6470

From correlation of elasticity of two distinct evaluations of tests with various medicines, it is watched that, there is a little change in their properties. The U.T.S of tempered examples was more than the standardized examples tempered examples. The malleable properties change with the network write, i.e martensitic (if there should arise an occurrence of extinguishing and treating) pearlitic (if there should be an occurrence of standardized examples), and bainite (in austempered tests) framework. In this manner prolongation increments, U.T.S and yield worry for tempered treatment (from $300 \mathrm{C}^{\mathrm{o}}$ to $600 \mathrm{C}^{\mathrm{o}}$ ) diminishes relying upon pearlite substance of the framework. Tempered examples have higher ductile properties than the standardized examples, yet as the hardening temperature is expanded there was an abatement in U.T.S and yield worry, as appeared in fig B1 and C1. The extension of tempered examples is higher than standardized examples, due to the development of martensite and tempere martensite and so on then again, the stretching increments with the hardening temperature as appeared in figure A. Looking at the two evaluations of tests $\mathrm{N} 1$ and $\mathrm{N} 2$, demonstrated that example with copper (N1 review) has higher UTS and Yield pressure and lesser prolongation than review N2 for both Normalized and Tempering Treatment.

\section{Austempering Treatment}

Austempering is a hardening process for metals which yields attractive mechanical properties including higher pliability, durability, quality for a castn hardness, protection from stun and lessened contortion, particularly with thin parts. Austempered pliable iron is created by warm treating thrown ductile iron to which little measures of nickel, molybdenum, or copper have been added to enhance hardenability. Particular properties are controlled by the watchful decision of heat treating parameters. Austempering includes the nucleation and development of acicular ferrite with in austenite, where carbon is rejected into the austenite.

Austempering is a heat treating process for mediumto-high carbon ferrous metals which creates a metallurgical structure called bainite. The properties condensed in Table 4 and Table 5, and figures demonstrates the variety of elasticity concerning the austempering time at temperature 300 degree celsius and 350 degree celsius separately for grades N1 and N2.
Table 4 and 5 Tensile Properties of Austempered ductile iron At $300 \mathrm{C}^{\circ}$ With and without Copper

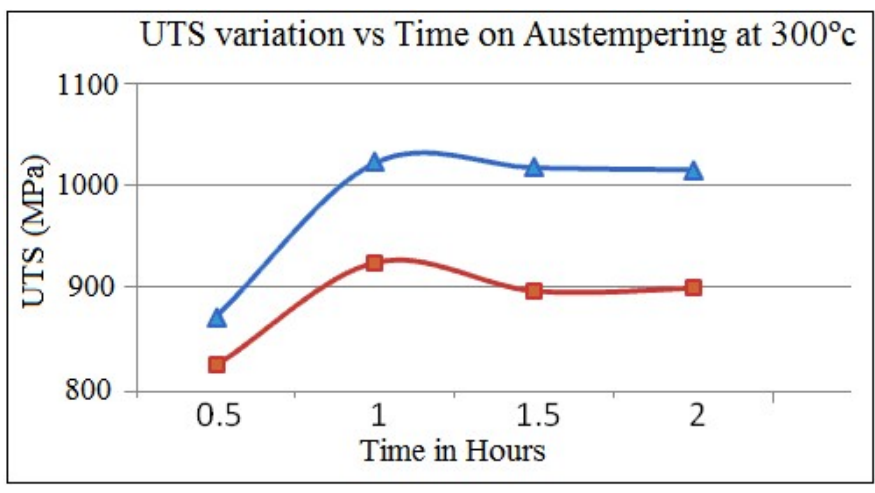

Variation of \% Elongation vs Time on Austempering at $300^{\circ} \mathrm{c}$

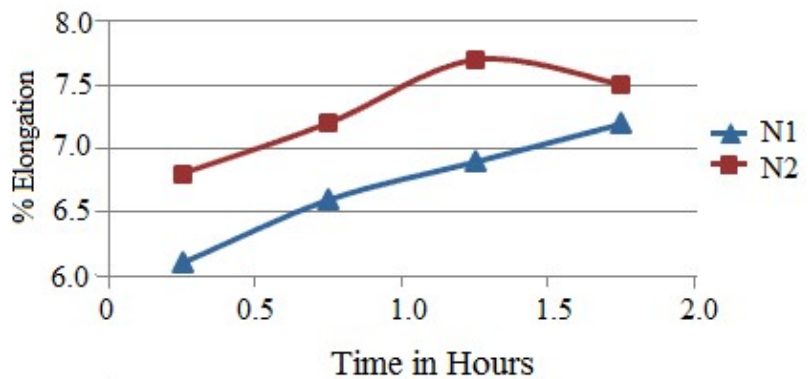

Y.S variation vs Time on Austempering at $350^{\circ} \mathrm{c}$
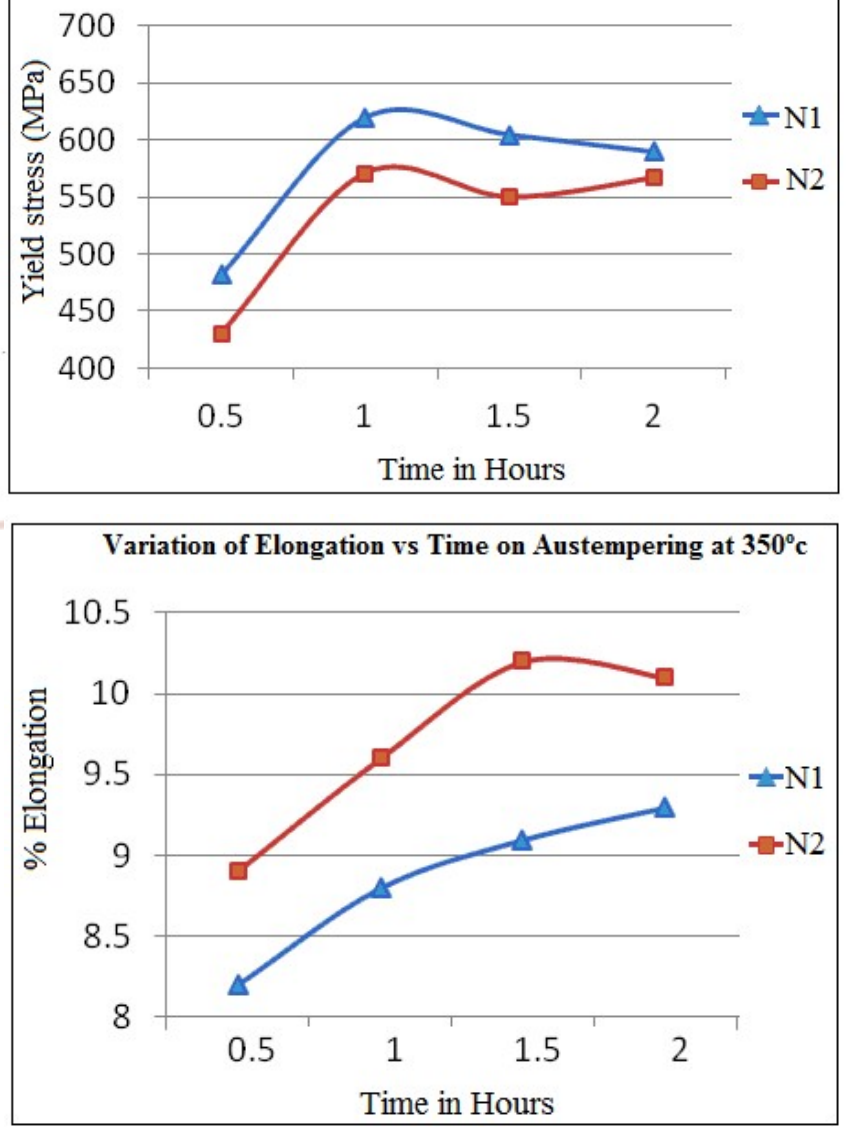
The Tensile quality is incremented at first from $0.5 \mathrm{hr}$ to $1 \mathrm{hr}$, at that point from $1 \mathrm{hr}$ to $2 \mathrm{hr}$ diminishes marginally for the two evaluations and with additionally increment in treatment time accomplishes a relentless state, as appeared in fig4 (a) and (b). The expansion in quality at first at low time interim is because of the high measure of martensite got from the unreacted austenite, however as the time increment over one hour the principal arrange response initiates in the intercellular locales for which quality abatements. With the further increment in time, the held austenite decreases, and malleability again increments w.r.t time. So flexibility expands further to a most extreme esteem which demonstrates the mediocre measure of martensite. The example alloyed with copper has expanded pliability and lesser quality than that example without copper content.

Extension for Austempered Ductile Iron (ADI) is expanding from $0.5 \mathrm{hr}$. to $1.0 \mathrm{hr}$. however, with slight diminished from $1.0 \mathrm{hr}$. to $2.0 \mathrm{hr}$. as appeared in figure 4.c and 5.c, which additionally demonstrates that (ADI) with copper is lower of that review without copper with little sum. Contrasting the rigidity and regard the austempering temperature for the two evaluations from table 3 , it is discovered that elasticity is diminishing with expanding austmpering temperature however stretching is Increasing ? Additionally the example with copper has higher malleability and lesser quality than that example without copper content .

\section{Uses Of spherulitic graphite cast Irons in different fields}

The uses of the S.G. iron have expanded massively lately as can be seen from the beneath mentioned equipments:

Tie rods

U-bolt stop plates

Wheel spindle

Connecting rods

Timing gears

Tripot housing

I-beams

Axle holder

Spring holder

Wheels

Motor wrench shaft

Brake caliper, circle - brake grapple, brake stay plate

Machine - device bed

Electric encasing post and top
Controlling knuckle

Jackhammer

Wedges Chain

sprockets

Chain sprockets

Mining wear parts

Moving plant rolls

Trim boxes and shape box clasps

Brake shoe for rock solid brakes

Glass molds

Spacer confine for moving bearing

Cylinder rings

Fertilizer knives Digger points

Corn grinder plates

Wear guides

Plow \& till points

\section{CONCLUSION}

The following observations were acquired tentatively amid Austempering heat treatment

I). Hardness normally decreases in the midst of the system of austempering. Also it was watched that the hardness regard reduces with the extension in time when the temperature was kept same (either $250^{\circ} \mathrm{Cor}$ $450^{\circ} \mathrm{C}$ degree or $\left.650^{\circ} \mathrm{C}\right), 2$. The strength and hardness values for the sample with copper are more while ductility was found to be more for the sample without copper

II) Sturdiness increments with increment in time and austempering treatment temperature and was altogether higher if there should be an occurrence of ADI tests with copper than without copper.

III) The tensile strength initially increases and then decreases in both samples with increase in time during Austempering Process

IV) Ultimate tensile strength and yield strength decreases while as elongation (ductility) increases with increase in temperature.

V) Amid process stretching first declines and after that increments.

For best combination of properties like ductility, Yield Strength, Hardness and Ultimate tensile strength one should opt austempering of the Spherulitic Cast iron as it is the most favourable method. 


\section{Future Scope:}

Building uses and engineering applications of ductile iron in as cast and diverse heat treated conditions are developing step by step. Austempered Ductile Iron's application has expanded colossally in numerous modern regions. Austempered Ductile Iron is progressively the material of selection of creators and specialists due to their savvy execution and it has started to replace steel in some structural and engineering applications. More work is needed to improve the properties like corrosion resistance, relative abrasive resistance and hardenability of ductile iron through studies on the effect of different alloying elements and heat treatment processes on the ductile iron

\section{REFERENCES}

1. Introduction to Physical Metallurgy; Sidney H. Avenar.

2. Davis J.R., ASM Specialty Handbook: Cast Irons, ASM International, 1996, pages 437.

3. Shaker M.A.; a note on the effect of nodulerization characteristics on the workability of quenched- hardened and tempered cast iron. Journal of Material processing technology, Volume 32, Issue 3, August 1992, pages 545-552.

4. S.P. Oudhira, "Quality demand an S.G.VIron Casting", Foundry, An Indian Journal for Progressive Metal-Casting, volume X No.4, JulyAugust, 1998, Pages 5-10.

5. Eric O., Sidjanin L., Miskovic Z. et. al.; Microstructure and toughness of $\mathrm{Cu}-\mathrm{Ni}-\mathrm{Mo}$ austempered ductile iron; Materials Letters, Volume 58, June 2004, Pages7-2711.

6. Eric O, Sidjanin L, Zec S, Jovanovic MT. Mater Letters,2004, Volume 58, Pages11-2707.

7. Fatahalla. N., Bahi. S.; Metallurgical parameters, mechanical properties and machinability of ductile cast iron, Journal of Materials Scienc (1996) 5765- 5772.
8. G. Krauss, Principles of Heat Treatment of Steel, ASM, 1980.

9. Mechanical properties of SG-iron with different matrix structure; journal of Material Science, Volume 36, 2001, Pages 1293-1300.

10. Hafiz Mohammad. Tensile properties and fracture of ferritic SG-iron having different-shell structure.

Z Metallkd Volume 11, 2001, Volume 1258-61.

11. Hydarzadeh M.,Nilli M.; The role of austempering parameter on the structure and mechanical properties of heavy section ADI, Journal of Material processing Technology, Volume 153-154, November 2004, Pages 203-208.

12. Hughes I.C.H., Austempered ductile iron: their properties and significance, Materials \& Design Vol. 6, July 1985.

13. Introduction to Physical Metallurgy; Sidney H. Avenar.

14. Jaun Manuel Velez, Tanaka V.K; Metallurgical \& Material Transaction A, Volume 29, December 1999, pages 2925-2934.

15. Kocatepe. Kadir, Cerah Melika, Erdogan Mehmet; The tensile fracture behaviour of intercritically annealed and quenched + tempered ferritic ductile iron with dual matrix structure; Journal of Materials and Design, July 2005, Pages 172-181.

16. Karsay, "Production of S.G. Irons". A guide to mechanical properties of ductile iron, Mid - Atlantic Casting service. Volume 9, chapter 6, Pages 70-90

17. Mechanical Metallurgy; G.E.Dieter New York: McGraw-Hill Co.; ASM, "Metals Handbook Metallography and Microstructures, Volume 9, 9th ed. (American Society of Metals).

18. Kim Yoon-Jun, Shin Hochoel; Investigation into mechanical properties of austempered ductile cast iron(ADI) in accordance with austempering temperature, materials Letters, Volume 62, May 2006, Pages 357-360. 